\title{
Island Constraints and Adjunct \& Argument Asymmetry in Turkish
}

\author{
Sinan Çakır \\ Adıyaman Üniversitesi, Fen Edebiyat Fakültesi, İngiliz Dili ve Edebiyatı Bölümü, Altınşehir \\ Mah. Atatürk Bulvart No: 1 02040, Merkez / ADIYAMAN \\ scakir@adiyaman.edu.tr
}

(Received 16 January 2016; accepted 23 September 2016)

\begin{abstract}
Due to the adjunct \& argument asymmetry in Turkish, the interpretation of argument wh-words within island structures does not result in ungrammaticality while that of wh-adjuncts results in ungrammaticality (Özsoy 1996, Arslan 1999, Görgülü 2006, Çakır 2015). Yet, the following questions are still unanswered: (1) When there are not any intervening islands in the interpretation of wh-words that originate in lower CPs, do we obtain the same results? (2) Is the observed different behavior of wh-elements a result of a more general adjunct-argument asymmetry that is indifferent to island effects? In the present study, the data were obtained through a Grammaticality Judgment Test containing 36 interrogative sentences from 435 participants. According to the results, the island constraints hold in Turkish, at least, for the sentence-level wh-adjuncts. However, it was also observed that there exists a general adjunct \& argument asymmetry in Turkish which is valid for all complex sentences no matter they are subject to island effects or not.
\end{abstract}

Keywords: syntax, adjunct \& argument asymmetry, island constraints

\section{Türkçede Ada Yapıları ve Ana Öğe-Eklenti Bakışımsızlığı}

ÖZ: Türkçede gözlemlenen ana öğe - eklenti bakışımsızlığı sebebiyle, ana öğe konumundaki ne-öbeklerinin ada yapısı içeren yapılardaki okumaları dilbilgisel sonuçlar verirken, eklenti konumundaki ne-öbeklerinin aynı durumdaki okumaları dilbilgisi dışı sonuçlar vermektedir (Özsoy 1996, Arslan 1999, Görgülü 2006, Çakır 2015). Ancak, cevaplanması gereken şu sorular mevcuttur: (1) Karmaşık tümcelerin yan tümceciklerinde bulunan neöbeklerinin okumalarında, tümcede herhangi bir ada yapısı mevcut değil ise, aynı sonuç elde edilmekte midir? Bir başka deyişle, ada yapıları gerçekten Türkçe tarzı dillerde işlevsel midir? (2) Türkçede ne-öbeklerinin sergilemekte olduğu farklı davranışlar ada yapılarına kayıtsız olan daha genel bir eklentiana öğe bakışımsızlığının bir sonucu mudur? Çalışmanın verileri 36 soru tümcesi içeren bir Dilbilgisellik Değerlendirme Testi ile 435 katılımcıdan elde edilmiştir. Çalışmanın bulgularına göre, ada yapıları tümce düzeyi neeklentilerini kapsayacak șekilde Türkçede işlevseldir. Ancak, ada yapılarına maruz olup olmasın tüm karmaşık tümceler için geçerli olan genel bir eklenti \& ana öğe bakışımsızlığının varlığı da gözlemlenmiştir. Ne- ana öğesi okuması hiçbir tümce yapısında sorun teşkil etmez iken, ne-eklentisinin alt tümce içerindeki okumaları herhangi bir ada yapısı mevcut değil iken bile 
sorunludur. Ada yapılarının mevcudiyeti durumunda ise, bu tümcelerin okumaları dilbilgisel olarak daha kabul edilemez bir hal almaktadır.

Anahtar Sözcükler: ne öbekleri, ada yapıları, eklenti-ana öğe bakışımsızlığı

\section{Introduction}

Syntactic structures out of which it is not possible to move are traditionally called "island constraints" since Ross (1967). He introduced a number of distinct island constraints like Complex NP Constraint, Sentential Subject Constraint and Coordinate Structure Constraint, one of which is exemplified below.

\subsection{Complex NP Constraint (CNPC)}

Movement is prohibited out of a noun phrase which includes a clause, either a nominal complement clause, or a relative clause. For instance;

(1) * When do you remember the young girl who you met?

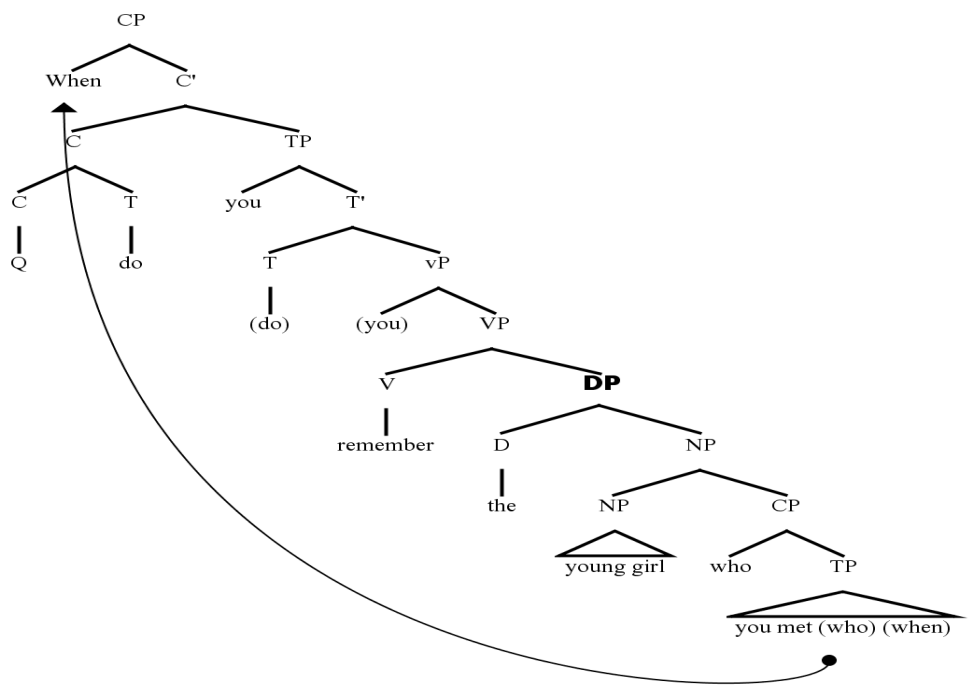

In this derivation, the wh-expression 'when' originates within the lower $\mathrm{CP}$ and moves to the specifier position of the matrix CP. However, this movement is prohibited by the DP that c-commands the lower CP. The derivation crashes and results in ungrammaticality. This constraint is called the Complex NP Constraint. 
After Ross (1967), the number of island constraints was extended with the works of the scholars like Kiparsky and Kiparsky (1970), Chomsky (1973), Ross (1984), Schafer (1995). New island constraints like Adjunct Island Constraint, Wh-Island Constraint, Negative Island Constraint, Factive Island Constraints, Right Roof Constraint and Left Branch Constraint were added to the list. The first one is given below as an example:

\subsection{Adjunct Island Constraint (AIC)}

Movement is prohibited out of an adjunct/adverbial. For instance;

(2) * For whom did Peter stay at home as he wanted to wait?

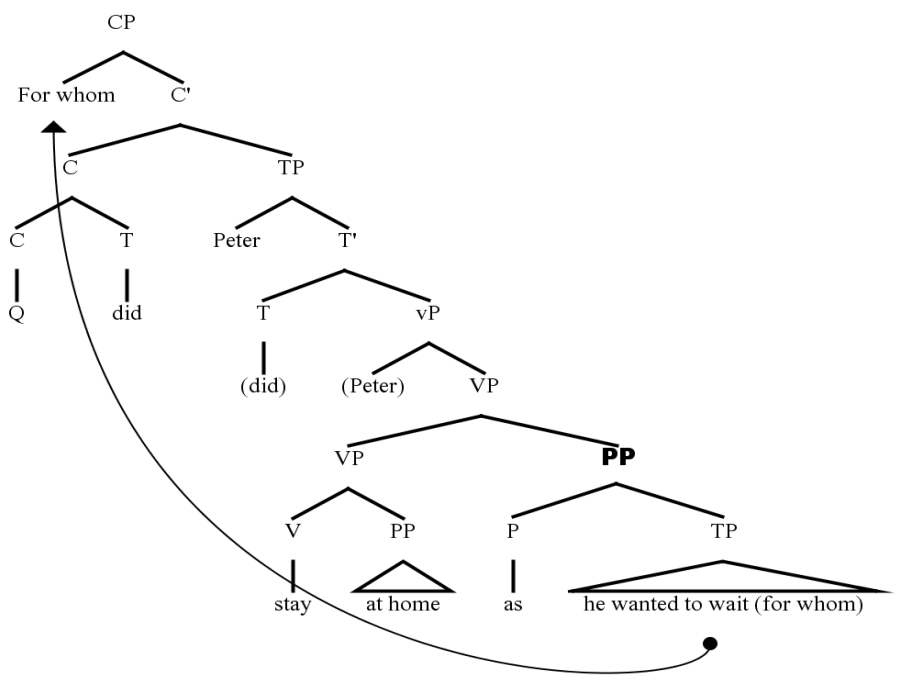

The wh-phrase 'for whom' originates within the adjunct clause. When it moves to the matrix spec CP position, it violates the Adjunct Island Constraint.

The island constraints were originally suggested for the overt wh-movement languages like English. Their functionality in wh-in-situ languages is a matter of debate among scholars.

\subsection{The Island Constraints in Wh-in-situ Languages}

Wh-in-situ languages and wh-movement languages show different characteristics in island constraints. In general, the ones that have overt whmovements are subject to island effects; however, such effects are not 
observed, or at least not so strictly observed, in wh-in-situ languages. Huang (1982) argues that LF movement, unlike syntactic movement is free from island effects. He notes that in Chinese, a language in which wh-movement is apparently not overt, no wh-island effects are observed. However, Huang's conclusion is challenged by Choe (1987) and Nishigauchi (1990). They claim that island effects are operative in wh-in-situ languages as well.

When the island constraints in Turkish are taken into account, Özsoy (1996) claims that the Subjacency Principle, which attempts to provide a unified account for the island constraints, holds in wh-in-situ languages as well. She proposes an alternative solution to the seemingly subjacency violations in Turkish: As she asserts, what moves in Logical Form to specifier position of the matrix clause in these constructions is indeed not the wh-phrase but the whole maximal projection that the wh-phrase is a constituent of. She also emphasizes the existence of argument-adjunct asymmetry in Turkish with regard to two island constraints on wh-movement: Complex NP and Adjunct Island constraints.

Her claims on argument-adjunct asymmetry are supported and extended by other scholars. For instance, Arslan (1999) emphasizes the argument-adjunct asymmetry on island constraints by stating that the interpretation of the argument wh-expressions in island structures is possible, whereas that of the adjunct wh-expressions is not. The following sentences taken from Arslan (1999, p.69) exemplify this asymmetry:

(3) Sen [[kimi davet eden] adam ]a kızın?

you who-ACC invite-REL man-DAT get.angry.at-PAST

'Who (x) is it such that you are angry at the man who invited $\mathrm{x}$ ?'

(4) *Sen [[Ayşe’yi niye davet eden] adam]a kızdın?

you Ayşe-ACC why invite-REL man-DAT get-angry-at-PAST

'Why ( $\mathrm{x})$ is it such that you are angry at the man who invited Ayşe' $\mathrm{x}$ ?

Both of the sentences above are subject to Complex NP Constraint. However, while the interpretation of a wh-argument (kimi 'who-Acc') in this structure is possible, that of a wh-adjunct (niye 'why') is not.

Similarly, Görgülü (2006) examines the role of four island constraints in Turkish (Wh-island, Complex NP, Subject Island and Adjunct Island Constraints) and supports the view that there is an argument-adjunct asymmetry on these island constraints in Turkish. After analyzing the island structures in Turkish, he draws the conclusion that except for some adjunct island structures, there is argument-adjunct asymmetry in the other three island constraints. As for the Adjunct Island Constraint, he claims that the argument-adjunct asymmetry is not observed on this constraint. 
On the other hand, Kornfilt (2008) claims that the Wh-island Constraint and Sentential Subject Constraint do not hold in Turkish while Coordinate Structure Constraint and Complex NP Constraint do (9-10). Yet, she makes these claims on relative clause structures rather than wh-phrases in Turkish. Melnick (2012) focuses on the Complex NP Constraint on wh-movement in Turkish and claims that this constraint does not hold in Turkish. According to him, the seemingly observed island violations in Turkish stem from cognitive processing difficulties rather than syntactic ones.

Çakır (2015) carried out a study to analyze the validity of the claims mentioned above relying on the intuitions of the native speakers of Turkish. In his study, 100 participants assessed the grammatical acceptability of the 27 interrogative sentences which contain three different island violations (Complex NP, Sentential Subject and Adjunct Island) in $-2,+2$ likert scale. The results of the study showed that there are both argument \& adjunct and VPlevel \& sentence-level adjunct asymmetries in Turkish. In fact, the real asymmetry in Turkish appeared to be between wh-arguments and sentencelevel wh-adjuncts. As for the VP-level wh-adjuncts, the results of the study suggested that VP level wh-expressions do not violate island structures altogether. They show unstable characteristics in this language. In most cases, the interpretation of such expressions in island structures does not result in ungrammaticality.

\subsection{The Present Study}

The present study is a follow-up study of Çakır (2015) and it aims to focus on some unanswered questions remaining from the previous study. According to the findings of Çakır (2015), there is adjunct-argument asymmetry in Turkish in the interpretation of wh-expressions within island structures. That is, while the interpretation of argument wh-words within island structures does not result in ungrammaticality, the interpretation of wh-adjunct within such structures results in ungrammaticality. Yet, the following questions were unanswered in the previous study.

1. When there are not any intervening island structures in the interpretation of wh-words in subordinate clauses of complex sentences do we obtain the same results? In other words, do the island constraints really hold in Turkish?

2. Is the observed different behavior of the wh-elements in Turkish a result of a more general adjunct-argument asymmetry that is indifferent to island effects? 
If the island constraints hold in Turkish, then, there should be a significant difference between the acceptability of the complex sentences that are subject to or not subject to island effects. And for the second research question, if the observed difference is just a result of a more general adjunct-argument asymmetry found in Turkish and which is indifferent to island effects, then, there should not be any difference in the acceptability of the interpretation of categorical wh-words in the simplex and complex sentences no matter they contain island structures or not.

\section{Method}

The data of the study were obtained through a Grammaticality Judgment Test containing 36 interrogative sentences. Before the application of this test, a pilot test which was composed of only the declarative versions of the test items was given to some participants. That is to say, the researcher wanted to assess whether or not the declarative versions of the interrogative sentences were regarded as grammatically acceptable by the participants. The reason for this application was that the researcher wanted to control the outer factors like sentence complexity, word choice or punctuation, which might influence the assessments of the participants. The test items were re-edited in accordance with the results of the pilot study.

In the main test of the study, a wh argument kim (who) and a wh-adjunct neden (why) were used in the test items. Half of the test items contained the wh-argument $\mathrm{kim}$ (who) and the other half contained the use of the wh-adjunct neden (why). (Only the test items containing the wh-adjunct neden (why) are exemplified below. Please see the Appendix to get the full test.)

In the test, there were three groups of test items. In the first group, the whwords originated within matrix clauses and these sentences are not subject to any island effects. This group was included in the study for control purposes. The following test item exemplifies this group:

(5) Metin sabahtan beri burada başbakanı görebilmek Metin morning-ABL since here-DAT prime.minister-ACC see-ABIL-INF için bekliyor.

in.order.to wait-PPROG

'Metin is waiting here since morning to be able to see the prime minister.'

Test Item 17. Metin sabahtan beri burada neden bekliyor? Metin morning-ABL since here-DAT why wait-PPROG? 'Why is Metin waiting here since morning?' 
In the second and third groups, the wh-words originated within subordinate clauses of complex sentences. While the ones in the second group are not subject to any island constraints, the ones in the third group are subject to either Complex NP Constraint, Sentential Subject Constraint or Adjunct Island Constraint. The reason for selecting these three island constraints among others is that they are the most frequently analyzed ones in the literature on island constraints phenomena in Turkish. The following test items exemplify these groups respectively:

(6) Ayşe [Merve'nin yeni bir araba alabilmek için para Ayşe Merve-GEN new a car buy-ABIL-INF (in order) to money biriktirdiğini] söyledi. save-NOM-POSS say-PAST.

'Ayşe said [that Merve saved money to buy a new car].'

Test Item 2. Ayşe [Merve'nin neden para biriktirdiğini] söyledi? Ayşe Merve-GEN why money save-NOM-POSS say-PAST? 'Why did Ayşe say [that Merve saved Money_t_]?'

(7) Erkan [[ onun kadın haklarını savunmak için Erkan he-GEN woman rights-ACC defend-INF (in order) to yazd1ğ1] kitab1] beğendi. write-NOM-POSS book-ACC like-PAST

'Erkan liked [the book [that she wrote to defend woman rights]]'

Test Item 9. Erkan [[onun neden yazd1 $\left.\breve{g ̆}_{1}\right] \quad$ kitab1] beğendi? Erkan he-GEN why write-NOM-POSS book-ACC like-PAST? 'Why did Erkan like[ the book[ that she wrote_t_]]?'

As seen in the examples above, both the declarative and interrogative versions of the test items were given to the participants. The reason for providing the declarative sentences before the interrogative ones was that the researcher wanted to make sure that the participants would not regard the second and third group of test items as scrambled wh-questions in which wh-words originated within matrix clauses and moved to the embedded clauses. That is to say, the researcher did not want the participants have a reading like "Erkan onun yazdığı kitabı neden beğendi?" (Why did Erkan like [the book [that she wrote]] -t_?).

The participants were asked to judge the grammatical acceptability of the 36 items on a $-2,+2$ Likert scale: -2 Points: "Totally Grammatically Unacceptable"; -1 Point: "Grammatically Unacceptable"; 0 Point: "I am not 
sure"; 1 Point: "Grammatically Acceptable"; and 2 points: "Totally Grammatically Acceptable". It was emphasized that they were required to assess only the interrogative sentences rather than their declarative versions. Besides, by putting a question mark at the end of all interrogative sentences and by strictly emphasizing that they are all interrogative, the researcher wanted to make sure that the participants would not get the assertive reading of the second group of test items.

The test was given to 435 participants (258 women and 177 men) online through the use of "Surveygizmo" survey preparation program at different times. The participants of the study are native speakers of Turkish who live in different parts of Turkey. Their age ranges from 18 to 45 (mean age: 26,2). They are either university students or university graduates. They have no prior knowledge of the island constraints on wh-movement.

\section{Data Analysis \& Discussion}

The findings of the study were statistically analyzed and presented below. The results obtained for the wh-argument kim (who) and wh-adjunct neden (why) are presented separately. Figure 1 below presents the findings for the test items that contain the use of wh-argument kim (who). In this figure, getting closer to $(-1)$ indicates that the participants regarded the test items as grammatically unacceptable, whereas getting closer to $(+1)$ means that they assessed these test items as grammatically acceptable. Although the test was carried out on $-2,+2$ scale, the findings were transformed to $+1,-1$ scale for the ease of the readers.

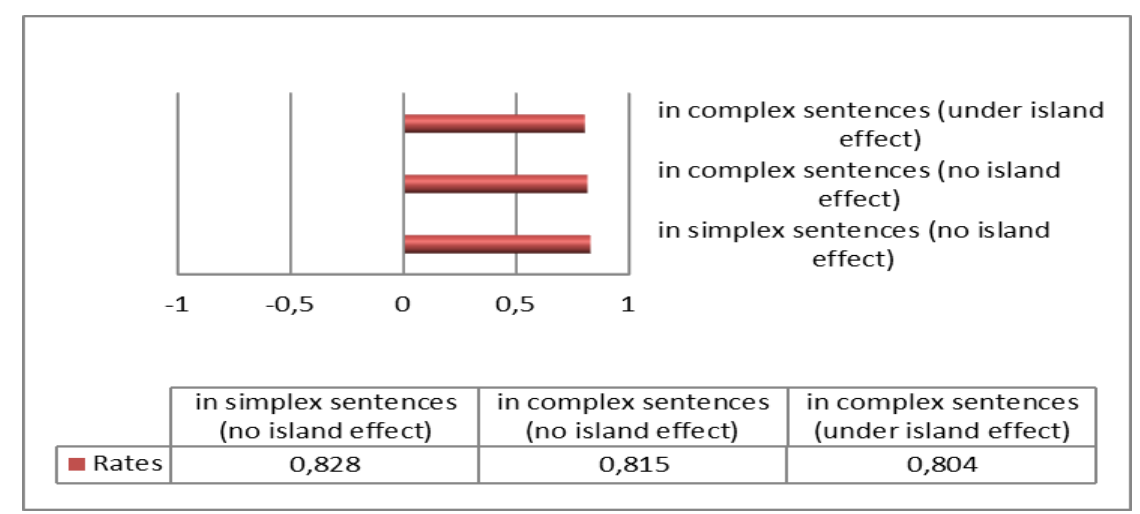

Figure 1: Findings for the wh-argument KIM (WHO)

According to the one way ANOVA results, there was not a statistically significant difference among the different sets of test items $[\mathrm{F}(2,3478)=1.48$, $\mathrm{p}=0.227]$. That is to say, according to the judgments of the participants, there 
was not a significant difference in the interpretation of wh-arguments in simplex or complex sentences no matter they are subject to island effects or not. All sets of test items were considered to be rather grammatically acceptable by the participants. Since there was not any statistically significant difference among the groups in the one way ANOVA results, there was no need to make further post hoc analyses.

These findings are consistent with the ones obtained in Çakır (2015). As indicated in the argument $\&$ adjunct asymmetry in Turkish, the interpretation of wh-arguments out of any structures (no matter they are subject to island effects or not) does not cause ungrammaticality. Hence, the data collected in the present study are in parallel with what has been proposed on wh-arguments so far: their interpretation out of other structures is not problematic in any case.

The data collected for this wh-argument are not sufficient to answer the research questions of the present study. To be able to answer the question: if island constraints really hold in Turkish or not, the data obtained for the whadjunct neden (why) has a key role, which are presented in Figure 2 below:

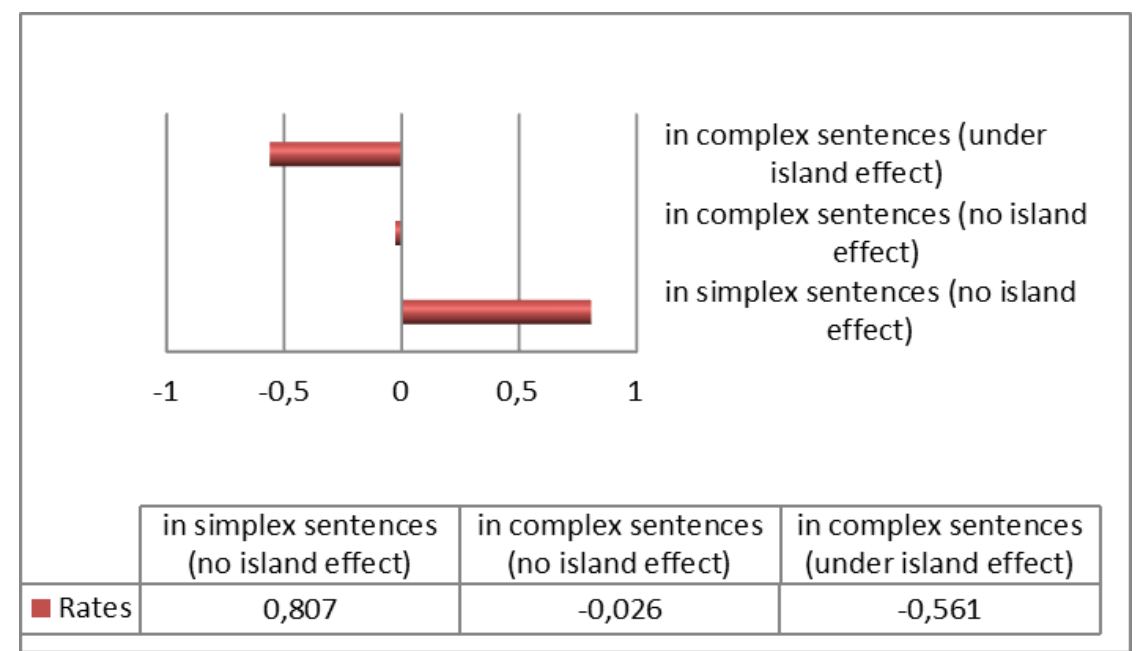

Figure 2: Findings for the wh-adjunct NEDEN (WHY)

According to the one way ANOVA results, there was a statistically significant difference among different sets of test items $[F(2,4314)=1792.80, p=0.001]$. Post hoc comparisons using the Tukey HSD test indicated that there was a statistically significant difference between all three groups of test items. The mean score for the test items that contain interpretation of the target wh-word in complex sentences under island effects was significantly worse than the ones 
that were not subject to island effects $(M=1.07, S=0.04, p=0.001)$. Similarly, they differed from the test items that have simplex structures without being subject to any island effect as well: $(M=2.75, S=0.04, p=0.001)$. The difference between the test items that contain interpretation of the wh-word in simplex and complex sentences without being subject to any island structures were significantly different as well: $(M=1.67, S=0.04, p=0.001)$.

The data above clearly show that island constraints hold in Turkish. When the wh-adjuncts originate within subordinate clause of complex sentences, their interpretation in this position appears to be sensitive to island effects. As it is shown in Figure 2, there is a significant difference in the acceptability of the complex sentences that are (not) subject to island effects. When there are intervening island structures, the sentences become significantly less acceptable. These findings reveal that island constraints hold in Turkish, at least for the sentence level wh-adjunct neden (why).

On the other hand, the findings of the study do not rule out the existence of a general argument \& adjunct asymmetry which is indifferent to island effects either. Figure 2 also indicate the existence of such an asymmetry in Turkish as well. That is to say, when the findings for the test items which have complex sentence structures and which are not subject to island effects are taken into account, it is observed that these test items were judged to be grammatically unacceptable by more than half of the participants. Besides, when the findings for this set of test items are compared with the ones that have simplex sentence structures, the difference is clearly significant. Hence, while the interpretation of the wh-adjuncts in simplex structures do not cause ungrammaticality, their interpretation in the subordinate clauses of complex sentences are significantly less acceptable even if there are not any intervening island structures. That is to say, the interpretations of adjuncts in complex sentence structures are always problematic. When there are intervening island structures, they become worse.

When we turn back to the findings for the wh-argument kim (who), there were not such differences in the interpretation of this wh-word in different sentence structures. Therefore, these findings indicate that there exist a general adjunct \& argument asymmetry in Turkish which is valid for all complex structures no matter they are subject to island structures or not. In the case of wh-arguments, their interpretations are not problematic in any case. As for the wh-adjuncts, their interpretation in the subordinate clauses are always problematic no matter there exists intervening island structures or not. However, when there are island structures as well, their interpretations have significantly worse results. 


\section{Conclusion}

The present study attempted to answer some of the remaining questions from Çakır (2015). In the obtained results, it was observed that island constraints really hold in Turkish, at least, for the sentence-level wh-adjuncts. However, it was also observed that there exist a general adjunct \& argument asymmetry in Turkish which is valid for all complex sentences no matter they are subject to island structures or not. The interpretation of wh-arguments is not problematic in any sentence structures; yet, the interpretation of wh-adjuncts in subordinate clauses is problematic even if there are not any intervening island structures. When there are island structures as well, their interpretations have significantly worse results, though.

The question that arises at this point is whether this generalization is valid for all types of sentence level wh-adjuncts or not. These wh-adjuncts in Turkish can be categorized into three groups: (1) wh-adverbials: neden, niye, niçin 'why'; (2) which-NP phrases: hangi amaçla 'for what reason', hangi sebeple 'with what purpose' and (3) wh-pronominals within post positional phrases: $n e$ için, ne diye 'for what'. If they all behave similarly, then, it is possible to conclude that "being an adjunct" is the sole cause of the ungrammaticality. However, if they display different characteristics, how can their different behaviors be explained syntactically? That is to say, what happens in overt syntax that cause them behave differently? In a further study, such questions can be dealt with to shed light on the status of the island constraints and the argument $\&$ adjunct asymmetry observed in Turkish.

\section{References}

Arslan, C. (1999). Approaches to wh-structures in Turkish. Unpublished MA thesis, Boğaziçi University, İstanbul, Turkey.

Choe, J. (1987). LF movement and pied-piping. Linguistic Inquiry, 18, 348-353.

Chomsky, N. (1973). Conditions on transformations. In S. Anderson \& P. Kiparsky (Eds.), A Festschrift for Morris Halle (pp. 232-286). New York: Holt, Reinhart \& Winston.

Çakır, S. (2015). Island constraints in Turkish: A Grammaticality Judgment Study. In D. Zeyrek, Ç. Sağın Şimşek, U. Ataş ve J. Rehbein (Eds.), Ankara Papers in Turkish and Turkic Linguistics (pp. 68-76). Wiesbaden: Harrassowitz Verlag.

Görgülü, E. (2006). Variable wh-words in Turkish. Unpublished MA thesis, Boğaziçi University, İstanbul, Turkey.

Huang, C.T. (1982). Logical relations in Chinese and the theory of grammar. Unpublished Ph. D. dissertation, MIT, Cambridge, Massachusetts.

Kiparsky, P. \& Kiparsky, C. (1970). Fact. In M. Bierwisch \& K. Heidolph (Eds.), Progress in Linguistics (pp. 143-173). The Hague: Mouton. 
Kornfilt, J. (2008). Some Observations on Turkish/Turkic RCs. [Paper given at Leipzig Spring School on Linguistic Diversity; MPI-EVA Conference, Leipzig.]

Melnick, R. (2012). Cognitive constraints and in-situ islands. [Paper given at the $9^{\text {th }}$ Annual QP Fest, Stanford University.]

Nishigauchi, T. (1990). Quantification in the theory of grammar. Dordrecht: Kluwer Academic Publishers.

Özsoy, S. (1996). A' dependencies in Turkish. [Paper given at the VI. Turkish Linguistics Conference; the School of Oriental and African Studies, London.]

Ross, J.R. (1967). Constraints on variables in syntax. Doctoral dissertation, Massachusetts Institute of Technology. Available online at http://hdl.handle.net/1721.1/15166.

Ross, H. (1984). Inner islands. In C. Brugman \& M. Macauley (Eds.), Proceedings of the Tenth Annual Meeting of the Berkeley Linguistics Society (pp. 258265). Berkeley Linguistics Society, University of California, Berkeley.

Schafer, R. (1995). Negation and verb second in Breton. Natural Language \& Linguistics Theory, 13. 135-172. 
Appendix: Dilbilgisellik Değerlendirme Testi (Grammaticality Judgment Test)

Verilen düz tümcelerden üretilmiş olan soru tümcelerinin Türkçe için uygun yapılar teşkil edip etmediğini -2 ve 2 arası puanlayarak değerlendiriniz. Bir başka deyişle, sorulan sorular dilbilgisel olarak kabul edilebilir mi? Yoksa bu soru tümceleri dilbilgisel olarak sorunlu mudur? Değerlendiriniz...

Puanlamanızı lütfen aşağıdaki ölçeğe göre yapınız.

2 puan: Dilbilgisel olarak kesinlikle kabul edilebilir

1 puan: Dilbilgisel olarak kabul edilebilir

0 puan: Emin Değilim

-1 puan: Dilbilgisel olarak kabul edilemez

-2 puan: Dilbilgisel olarak kesinlikle kabul edilemez

Örnek:

Ahmet bu sabah İzmir'e gitti.

1. Ahmet bu sabah nereye gitti?

ÖNEMLİ NOT (1): Lütfen sözcüklerin yerlerini DEĞIŞTIRMMEDEN, soru tümcelerini bu halleriyle değerlendiriniz.

A) Ne Ana Öğesi Kì'i İçeren Test Maddeleri

(The test items containing the wh-argument KIM 'WHO')

A-1) 1. Grup (Ana cümlede; Ada etkisi yok)

(In the main clause; No island effect)

Meral okuldan çıtıktan sonra amcasını görmeye gitti.

1. Meral okuldan çıktıktan sonra kimi görmeye gitti?

$\mathrm{Bu}$ sorunun cevabını sadece Ahmet biliyor.

2. Bu sorunun cevabını sadece kim biliyor?

Aylin kendisine haksızlık yapıldığını öğretmenine söyledi.

3. Aylin kendisine haksızlık yapıldığını kime söyledi?

Erkan caddede yürürken ilkokul arkadaşına rastladı.

4. Erkan caddede yürürken kime rastladı?

Ahmet'in oraya gittiğini sadece Mesut görmüş.

5. Ahmet'in oraya gittiğini sadece kim görmüş?

Metin'in dün akşam eve giderken eski kız arkadaşını gördü.

6. Metin dün akşam eve giderken kimi gördü? 
A-2) 2. Grup (Yan cümlecikte; Ada etkisi yok)

(In the Embedded Clause; No island effect)

Betül yarışmayı Kerem'in kazanacağını düşünüyor.

1. Betül yarışmayı kimin kazanacağını düşünüyor?

Sevil Metin'in Derya'ya aşı olduğunu sanıyor.

2. Sevil Metin'in kime aşık olduğunu sanıyor?

Murat bu sabah Elif'i gördüğünü söyledi.

3. Murat bu sabah kimi gördüğünü söyledi?

Serap benim dün akşam Ebru'yu aradığımı sanıyor.

4. Serap benim dün akşam kimi aradığımı sanıyor?

Selim masanın üstündeki parayı Metin'in çaldığının düşünüyor.

5. Selim masanın üstündeki parayı kimin çaldığını düşünüyor?

Merve Ayşe'nin çok üzgün olduğunu söyledi.

6. Merve kimin çok üzgün olduğunu söyledi?

\section{A-3) 3. Grup (Yan cümlecikte; Ada etkisi var)}

(In the Embedded Clause; Under island effect)

Burcu'nun teyzesine gönderdiği hediye bu sabah ulaşmış.

1. Burcu'nun kime gönderdiği hediye bu sabah ulaşmış? (CNPC)

Ahmet ablasının gönderdiği mektubu okudu.

2. Ahmet kimin gönderdiği mektubu okudu?

(CNPC)

Hırsız yaşı ı kadının çantasını çaldıktan sonra koşarak uzaklaştı.

3. Hırsız kimin çantasını çaldıktan sonra koșarak uzaklaştı?

Meral eski eşini görünce ağlamaya başladı.

4. Meral kimi görünce ağlamaya bașladı?

Eşinin aniden eve gelmesi Ayşe'yi şaşırttı.

5. Kimin aniden eve gelmesi Ayşe'yi şaşırttı?

Mustafa' nın eski kı arkadaşını araması Merve'yi sinirlendirdi.

6. Mustafa'nın kimi araması Merve'yi sinirlendirdi?

(SSC)

B) Ne- Eklentisi NEDEN'i İçeren Test Maddeleri

(The test Items containing the wh-adjunct NEDEN 'WHY')

B-1) 1. Grup (Ana cümlede; Ada etkisi yok)

(In the main clause; No island effect)

Öğrenciler dün akşam şehir merkezine alışveriş yapmak için gittiler.

1. Öğrenciler dün akşam şehir merkezine neden gittiler?

Murat ve Selim oyuncakları paylaşamadıkları için kavga ediyorlar.

2. Murat ve Selim neden kavga ediyorlar?

Aysel teyze dün bizim eve annemi ziyaret etmek için gelmiş.

3. Aysel teyze dün bizim eve neden gelmiş?

Yaşlı adam yıllardır oturduğu evini oğlunu okutabilmek için sattı.

4. Yaşıı adam yıllardır oturduğu evini neden sattı? 
Canan beni dün sabah sınavın saatini öğrenmek için aramış.

5. Canan beni dün sabah neden aramış?

Metin sabahtan beri burada başbakanı görebilmek için bekliyor.

6. Metin sabahtan beri burada neden bekliyor?

B-2) 2. Grup (Yan cümlede; Ada etkisi yok)

(In the Embedded Clause; No island effect)

Ayşe Merve'nin yeni bir araba alabilmek için para biriktirdiğini söyledi.

1. Ayşe Merve'nin neden para biriktirdiğini söyledi?

Burcu benim toplantıya şirketteki sorunları anlatmak için katılacağımı sanıyor.

2. Burcu benim toplantıya neden katılacağımı sanıyor?

Metin Kerem'in oyuncağı kırıldığı için ağladığını söyledi.

3. Metin, Kerem'in neden ağladığını söyledi?

Murat, Serap'ın bu sabah okula arkadaşlarıyla vedalaşmak için geldiğini sanıyor.

4. Murat Serap'ın bu sabah okula neden geldiğini sanıyor?

Cem Murat'ın kendisine bilgi vermek için telefon edeceğini düșünüyor.

5. Cem Murat'ın kendisine neden telefon edeceğini düşünüyor?

Burcu Ahmet'in oraya Elif'i görmek için gideceğini düşünüyor.

6. Burcu Ahmet'in oraya neden gideceğini düşünüyor?

\section{B-3) 3. Grup (Yan cümlede; Ada etkisi var)}

(In the Embedded Clause; Under island effect)

Erkan onun kadın haklarını savunmak için yazdığ kitabı beğendi.

1. Erkan onun neden yazdığı kitabı beğendi?

(CNPC)

Murat'ın özür dilemek için yazdığı mektup oldukça uzun.

2. Murat'ın neden yazdığı mektup oldukça uzun?

(CNPC)

Seval, Ahmet'e kendisini rahatsız ettiği için kızdıktan sonra telefonu kapattı.

3. Seval Ahmet'e neden kızdıktan sonra telefonu kapattı?

(AIC)

Ayşe, Erhan kendisine sessiz olması için bağırınca çok korktu.

4. Ayşe Erhan kendisine neden bağırınca çok korktu?

Serap'ın bu sabah okula ders notlarını vermek için gelmesi bizim için iyi oldu.

5. Serap'in bu sabah okula neden gelmesi bizim için iyi oldu? (SSC)

Cem'in iș bulamadığ 1 için sinirlenmesi bizi üzdü.

6. Cem'in neden sinirlenmesi bizi üzdü?

ACRONYMS:

CNPC: Complex NP Constraint

AIC: Adjunct Island Constraint

SSC: Sentential Subject Constraint 